\title{
Prototyping of a High Frequency Phased Array Ultrasound Transducer on a Piezoelectric Thick Film
}

\author{
Nikola Bunčić ${ }^{1}$, Anton Kabaší2, Tonći Čakarić ${ }^{2}$ Ante Bilušić ${ }^{2}$ \\ ${ }^{1}$ INETEC - Institute for nuclear technology Ltd., Lučko, Croatia \\ ${ }^{2}$ University of Split, Faculty of Science, Split, Croatia
}

\begin{abstract}
A process including virtual prototyping of a high frequency phased array ultrasound transducer on a piezoelectric thick film using a finite element method (FEM) is shown. Generated FEM models were based on PMN-PT (Pb(Mg1/3Nb2/3)O3-PbTiO3) thick films, made by sol-gel technique, with the thickness vibrational mode resonant frequency of each film being close to $28.5 \mathrm{MHz}$. Ultrasound transducers with such characteristics, due to their size and high frequency, are suitable for use in small medical diagnostic tools intended for use in delicate and sensitive areas (for example in ophthalmology and dermatology). With respect to their size, the transducers should retain very good focusing, beam steering and other advantages that phased array layout offers. To ensure an optimal performance of the phased array ultrasound transducer on such a piezoelectric thick film, several electrode patterns were used and tested in FEM simulations with the end goal of getting best performance from the PMN-PT thick films. A 64-element configuration was shown to be a promising technological solution for ophthalmological ultrasound diagnostics.
\end{abstract}

Keywords: Phased Array, Thick Film, PzFlex/OnScale, High Frequency, PMN-PT

\section{Izdelava prototipa visokofrekvenčnega faznega polja ultrazvočnih pretvornikov na debelo plastnem piezoelektriku}

Izvleček: $\vee$ članku je prikazan proces virtualne izdelave prototipa visokofrekvenčnega polja ultrazvočnih pretvornikov na debelo plastnem piezoelektriku na osnovi FEM metode. Generirani FEM modeli temeljijo na PMN-PT filmih, ki so narejeni na tehnologiji sol-gel in sicer z debelino z vibracijsko resonančno frekvenco blizu $28.5 \mathrm{MHz}$. Ultrazvočni pretvorniki teh dimenzij in frekvenc so primerni za uporabo v majhnih medicinski diagnostični opremi za uporabo v občutljivih območjih (npr. oftalmologija in dermatologija). Zaradi svoje majhnosti naj bi pretvorniki zagotavljali dober fokus in vodenje žarka. Za doseganje optimalnega delovanja so bili obravnavani bili številni vzorci faznega polja ultrazvočnih pretvornikov. Izkazalo se je, da je, za uporabo v oftalmologiji, najboljša kombinacija s 64 elementi.

Ključne besede: fazno polje, debele plasti, PzFlex/OnScale, visoka frekvenca, PMN-PT

*Corresponding Author'se-mail:akabasi@pmfst.hr, tonci@pmfst.hr,bilusic@pmfst.hr

\section{Introduction}

In modern medicine ultrasound is still an important diagnostic tool, despite development of new and advanced diagnostic techniques. Ophthalmology is probably the most illustrative example: although optical diagnostic methods are more present in medical practices, in cases of blur of the eye caused by a trauma or a disease, ultrasound is still the best way to look inside the eye. Ultrasound ophthalmological instrumentation available on the market is generally based on vibrating piezoelectric bulk transducers generating a single ultrasound wave. Such technology limits the highest available frequency, the minimum focus depth, and the minimum plane-wave formation distance. 
Imaging of anterior eye chamber is rather important since precursors of many eye diseases create in it. Due to their generally low ultrasound frequency, this front part of the eye cannot be probed with high resolution by present ultrasound diagnostic tools. Since the resonant frequency of piezoelectric material inversely depends on its thickness, implementation of thick piezoelectric films as ultrasound-source material would increase the frequency to tens or hundreds $\mathrm{MHz}$ range. For ophthalmology applications such frequencies are targeted ones, since they can enable to probe microstructures on distances of few millimeters from the transducer. Linear array of micro-transducers based on a piezoelectric film could improve the overall performance further, since, by tuning the phase of each micro-transducer ultrasound, the diagnostic ultrasound wave can be focused in a controllable way. Although many research efforts are taken to create such phasetuned linear arrays [1-8], they still cannot be routinely created. The major difficulty is the preparation of highquality piezoelectric films of thickness of few or few tens of micrometers convenient for such applications (problems with ultrasound cross-talk). Further, as resonant frequency of the film increases, the size of a single micro-transducer decreases to size that makes traditional mechanical cutting techniques inapplicable.

Recent studies show drawbacks of thinned bulk ceramics over piezoelectric films [9-11]: in the piezoelectric films higher vibration amplitudes can usually be present, with smaller hysteresis, and the films can produce higher energy densities with lower power requirements. Thick films of lead magnesium niobium titanate (PMN-PT) have superior piezoelectric and dielectric constants when compared to zinc-oxide ( $\mathrm{ZnO}$ ) and lead zinc titanate (PZT) [12-19], distinguishing them as the main candidates for high-frequency ultrasound transducers.

In this paper we show a finite element modelling (FEM) analysis of different configurations of metallic electrodes deposed on a thick piezoelectric film. Each electrode with the piezoelectric film beneath is considered as an ultrasound micro-transducer. The modelling is based on properties of PMN-PT film available in our laboratory and can be used for experimental realization of studied models.

\section{Sample properties}

The acoustically active basis for the FEM analysis presented here is a set of PMN-PT $\left(\mathrm{Pb}\left(\mathrm{Mg}_{1 / 3} \mathrm{Nb}_{2 / 3}\right) \mathrm{O}_{3}^{-}\right.$ $\mathrm{PbTiO}_{3}$ ) thick films. Films were deposited by screenprinting at the Jožef Stefan Institute, Ljubljana, Slovenia (details of film preparation are given on [20-22]).
Fig. 1 shows a cross section of the film imaged by a FEI Apreo scanning electron microscope. The films thicknesses are around $30 \mu \mathrm{m}$, with the average grain size of $5 \mu \mathrm{m}$. For the electrical characterization we used a vector network analyzer Bode 100 of Omicron Lab. Fig. 2 gives the electrical impedance $Z$ (top) and the phase angle $\phi$ (bottom):

$$
\phi=\arctan \frac{\operatorname{Im}(Z)}{\operatorname{Re}(Z)}
$$

where $\operatorname{Im}(Z)$ and $\operatorname{Re}(Z)$ are the imaginary and real parts of the electrical impedance, respectively. The impedance is measured on the whole sample area. Due to structural homogeneity of the active layer (see Fig. 1), we assume that electrical properties are homogenous as well. It shows broad antiresonance-resonance peaks at $1.7 \mathrm{MHz}$ and $28.5 \mathrm{MHz}$ respectively, that indicates weak electromechanical coupling. Resonant frequency of $28.5 \mathrm{MHz}$ is used in the FEM analysis presented later in the text. Models used for the FEM analysis are based on four samples of phased array ultrasound transducers on a piezoelectric thick films, all made with 16 electrodes. The layout of the samples is shown in Figure.3.

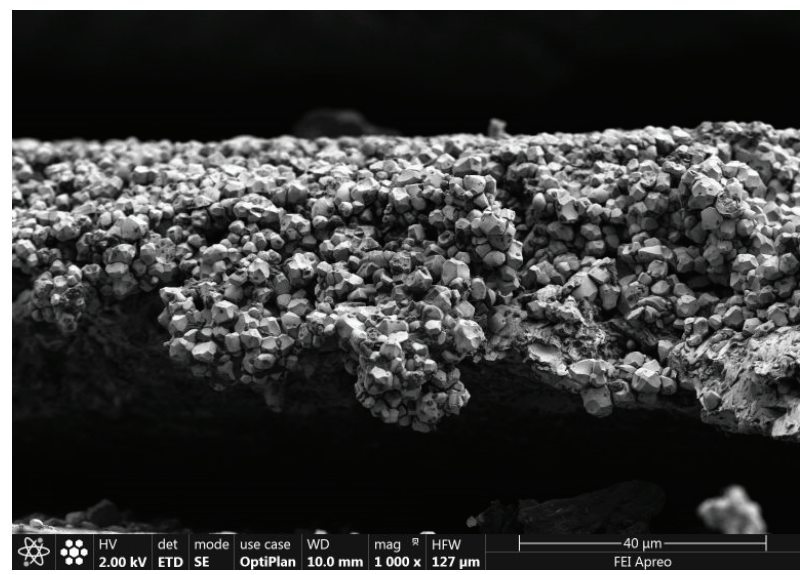

Figure 1: A scanning electron microscope image of the cross-section of the PMN-PT film.

The material properties of the phased array ultrasound transducer on a piezoelectric thick film and other geometrical parameters are given in Table.1.

Table 1: Phased array ultrasound transducer parameters.

\begin{tabular}{|c|c|c|c|c|c|}
\hline Layer & Material & Function & Width & Length & Thickness \\
\hline 1 & $\mathrm{Al}_{2} \mathrm{O}_{3}$ & Substrate & $5,4 \mathrm{~mm}$ & $6,0 \mathrm{~mm}$ & $3,0 \mathrm{~mm}$ \\
\hline 2 & $\mathrm{Au}$ & Ground & $5,4 \mathrm{~mm}$ & $6,0 \mathrm{~mm}$ & $10 \mu \mathrm{m}$ \\
\hline 3 & $\mathrm{PMN}-\mathrm{PT}$ & Piezoelectric & $5,4 \mathrm{~mm}$ & $6,0 \mathrm{~mm}$ & $30 \mu \mathrm{m}$ \\
\hline 4 & $\mathrm{Al}$ & Electrode & $10 \mu \mathrm{m}$ & $4,0 \mathrm{~mm}$ & $\leq 10 \mu \mathrm{m}$ \\
\hline
\end{tabular}


a)

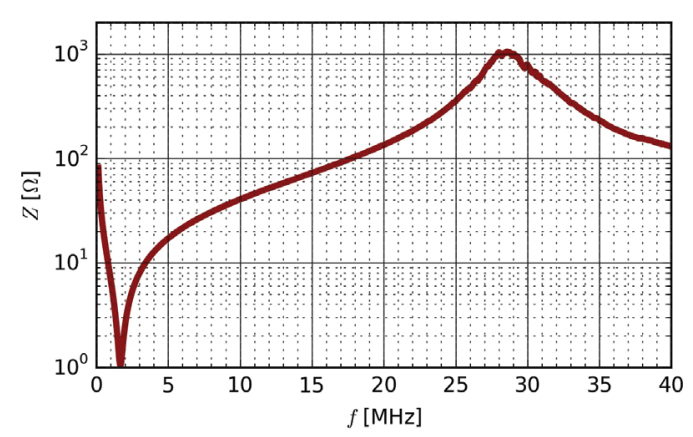

b)

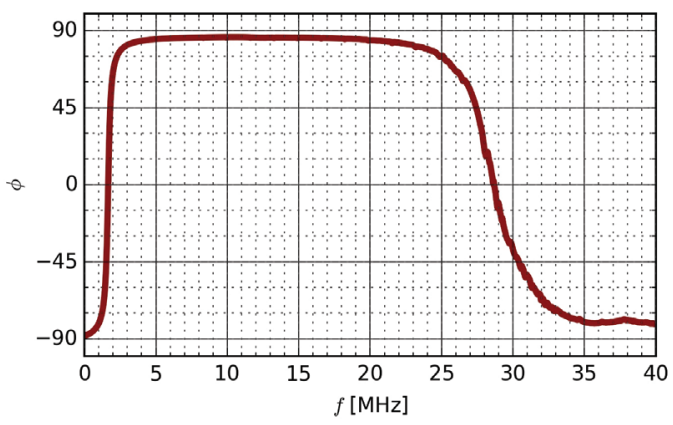

Figure 2: Frequency dependence of the electrical impedance (top) and the phase angle (bottom) of the tested PMN-PT film. Broad resonance-antiresonance frequency interval indicates weak electro-mechanical coupling.

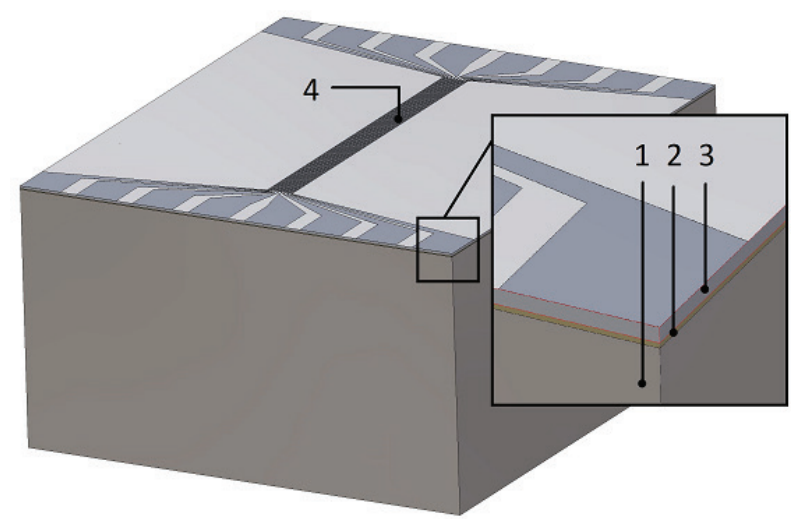

Figure 3: Phased array ultrasound transducer on a piezoelectric thick film layout

The main difference between the four models is in the electrodes arrangement. For example, the samples differ in pitch, aperture, etc. These parameters have critical influence on transducers performance; they are shown in Table 2.
Table 2: Electrodes arrangement on the transducer samples

\begin{tabular}{|c|c|c|c|c|c|}
\hline${ }_{A}{ }_{A}{ }_{A}$ & W & A & $p$ & $\mathrm{~g}$ & e \\
\hline Sample 1 & $4 \mathrm{~mm}$ & $\begin{array}{c}0,310 \\
\mathrm{~mm}\end{array}$ & $\begin{array}{r}20 \\
\mu m\end{array}$ & $\begin{array}{c}10 \\
\mu \mathrm{m}\end{array}$ & $\begin{array}{r}10 \\
\mu \mathrm{m}\end{array}$ \\
\hline Sample 2 & $4 \mathrm{~mm}$ & $\begin{array}{c}0.385 \\
\mathrm{~mm}\end{array}$ & $\begin{array}{r}25 \\
\mu \mathrm{m}\end{array}$ & $\begin{array}{r}15 \\
\mu m\end{array}$ & $\begin{array}{r}10 \\
\mu \mathrm{m}\end{array}$ \\
\hline Sample 3 & $4 \mathrm{~mm}$ & $\begin{array}{c}0,460 \\
\mathrm{~mm}\end{array}$ & $\begin{array}{r}30 \\
\mu \mathrm{m}\end{array}$ & $\begin{array}{l}20 \\
\mu \mathrm{m}\end{array}$ & $\begin{array}{r}10 \\
\mu \mathrm{m}\end{array}$ \\
\hline Sample 4 & $4 \mathrm{~mm}$ & $\begin{array}{c}0,610 \\
\mathrm{~mm}\end{array}$ & $\begin{array}{r}40 \\
\mu \mathrm{m}\end{array}$ & $\begin{array}{l}30 \\
\mu \mathrm{m}\end{array}$ & $\begin{array}{r}10 \\
\mu \mathrm{m}\end{array}$ \\
\hline
\end{tabular}

\section{Results of fem analysis}

2D model set-up is a multilayer structure with crosssection arranged in the same way as the model from Figure 3, while electrode-arrangement dimensions are as specified in Table 1.

Acoustic, piezoelectric, damping, dielectric and other properties of materials used are predefined in PzFlex material database [23].

A 2D model was set up to simulate the propagation of sound waves through a $3 \mathrm{~mm}$ water column, with the central frequency being $28.5 \mathrm{MHz}$ and the amplitude peak being $100 \mathrm{~V}$. The analysis showed weak focus-

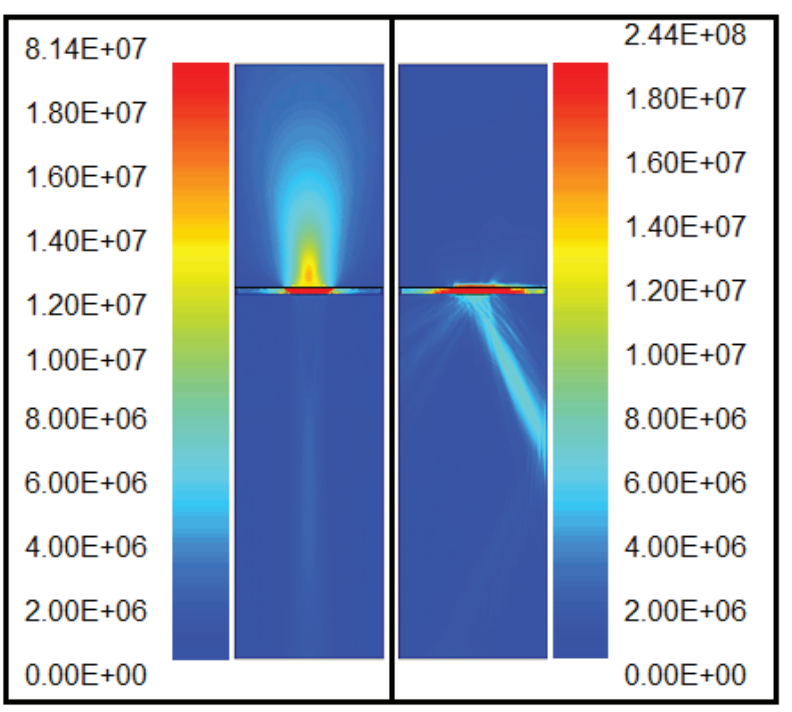

a)

b)

Figure 4: Maximum acoustic pressure of Sample 1 configuration: a) focusing b) beam steering. Color scale values are in $\mathrm{Pa}$, while model domain dimensions are $2 \times 8 \mathrm{~mm}$. 
ing and good beam steering $\left(25^{\circ}\right)$ properties of these transducers. Bad focusing properties are visible in maximum acoustic pressure field graphic view (see Figure 4a), which shows a weak pressure field under the transducer and a lack of focus. The focusing of the passed array transducer was simulated by delaying the signal excitation on electrodes and the focal point was set to $3 \mathrm{~mm}$ depth on the bottom of the water column, but the simulation results differ.

The weak focusing of the passed array transducer can be verified by calculating its near-field value, because the near-field gives the maximum depth for the usable focus for a given passed array configuration. Near-field values are given by the following equation:

$N=\frac{D^{2} f}{4 c}[m m]$

where:

$D=n p[\mathrm{~mm}]$ for active phased array axis

$D=W[\mathrm{~mm}]$ for passive phased array axis

$n$ - electrode number

$W$ - passive aperture [mm]

$f$ - frequency $[\mathrm{Hz}]$

$c$ - speed of sound through material $[\mathrm{mm} / \mathrm{s}]$

From Equation (2) it is calculated that the near-field value on the passive axis (i.e. the axis that cannot be focused) is $N_{p}=77.03 \mathrm{~mm}$, but the near-field value on the active axis, depending on a model, is $N_{\text {a1 }}=0.5 \mathrm{~mm}$ (for $p=20 \mu \mathrm{m}$ ), $N_{\mathrm{a} 2}=0.77 \mathrm{~mm}$ (for $p=25 \mu \mathrm{m}$ ), $N_{\mathrm{a} 3}=1.11 \mathrm{~mm}$ (for $p=30 \mu \mathrm{m}$ ) and $N_{\mathrm{a} 4}=1,97 \mathrm{~mm}$ (for $p=40 \mu \mathrm{m}$ ). Near-field values on the active axis clearly show weak focusing capabilities of the current transducer setup, which needs to be improved. Bad focusing properties also affect the beam steering because the beam dissipates and widens after the focal point.

The tested transducer setups have pronounced side lobes and there is a grating lobes formation at higher pitch values $(30 \mu \mathrm{m}$ and $40 \mu \mathrm{m})$. The side lobes are produced by an acoustic pressure leaking from probe elements at a different angle. Grating lobes are generated by the acoustic pressure due to even sampling across the probe element and they can be reduced by alternating the probe pitch, and keeping it below $\lambda / 2$ value, if possible.

\subsection{Modifying transducer setup}

Referring to previously shown results, it is obvious that the main point of improvement is the focusing capability. Improvement of this capability can be done by modifying the electrodes arrangement. This can be done by increasing the electrode width $(e)$ in some degree, because the electrode width affects the pitch $(p)$ and the increasing of the electrode spacing $(g)$ has an effect on the pitch. Changing pitch values is limited because it has a great impact on the grating lobes. The next option would be increasing the number of electrodes $(\mathrm{n})$, which means going from 16 element phased array to 32 or 64 elements, and as well the electrode length should be corrected to balance the passive and active phased array axis. To limit the grating lobes, the pitch should be $p<\lambda / 2$, but the general rule allows a pitch value up to $p<0.67 \lambda$. Respecting this pitch limitation, near-field values are calculated for 32 and 64 elements electrodes configuration. The calculated values are shown in Table 3.

Table 3: Data calculated for different passed array transducer configurations.

\begin{tabular}{|c|c|c|c|c|c|c|c|}
\hline $\mathrm{n}$ & $\begin{array}{c}p \\
{[\mu \mathrm{m}]}\end{array}$ & $\begin{array}{c}\mathrm{e} \\
{[\mu \mathrm{m}]}\end{array}$ & $\begin{array}{c}g \\
{[\mu \mathrm{m}]}\end{array}$ & $\begin{array}{c}\mathrm{A} \\
{[\mathrm{mm}]}\end{array}$ & $\begin{array}{c}\mathrm{W} \\
{[\mathrm{mm}]}\end{array}$ & $\begin{array}{c}\mathrm{Na} \\
{[\mathrm{mm}]}\end{array}$ & Rule \\
\hline 32 & 25 & 10 & 15 & 0.785 & 0.8 & 3.1 & \multirow{2}{*}{$\begin{array}{c}p<\lambda / 2 \\
(\lambda / 2=26 \mu \mathrm{m})\end{array}$} \\
\hline 64 & 25 & 10 & 15 & 1.105 & 1.6 & 12.3 & \\
\hline 32 & 30 & 10 & 20 & 0.94 & 0.96 & 4.4 & \multirow[b]{2}{*}{$\lambda / 2<p<0.67 \lambda$} \\
\hline 64 & 30 & 10 & 20 & 1.26 & 1.9 & 17.8 & \\
\hline 32 & 35 & 15 & 20 & 1.1 & 1.12 & 6 & \multirow[b]{2}{*}{$p<0.67 \lambda$} \\
\hline 64 & 35 & 15 & 20 & 1.58 & 2.2 & 24.2 & \\
\hline
\end{tabular}

Values of the passive aperture (W) are now similar to the values of the active aperture $(A)$ - they are chosen in this way to balance out the near-field values on the passive and active passed array axes (see Table 3 ).

\subsection{Additional FEM analysis}

Newly acquired electrode arrangement parameters on a phased array transducer must be verified by a FEM analysis software, so the additional FEM analysis was conducted with identical driving conditions (time function, frequency, voltage peak) as before. For additional analysis, two highlighted configurations from Table 3 are used for the 2D model setup. This is due to decent near-field values, which should mean that the transducers setups in this manner should have decent focusing depths.

The FEM analysis showed good focusing properties on chosen configurations $(n=64, p=30 \mu \mathrm{m}$ and $n=64$, $p=35 \mu \mathrm{m}$ ). The analysis was set to simulate the $6 \mathrm{~mm}$ focus in a $7 \mathrm{~mm}$ high water column. The new configuration manages to successfully focus at the wanted depth, which is visible in the higher maximum acoustic pressure values around the wanted focusing depth (see Figure 5). 
The 16 electrodes configuration produced higher-pressure values (see Figure 4) due to very long electrodes $\left(\mathrm{W}_{\text {passive }}>>\mathrm{A}\right)$ but focusing capabilities were poor. The 64 electrodes configuration produced smaller pressure values (Figure 5) but it had much better-focusing capabilities, and electrodes length was corrected on this configuration $\left(\mathrm{W}_{\text {passive }}=\mathrm{A}\right)$. It is important to mention that pressure values will also change with different focusing depths.

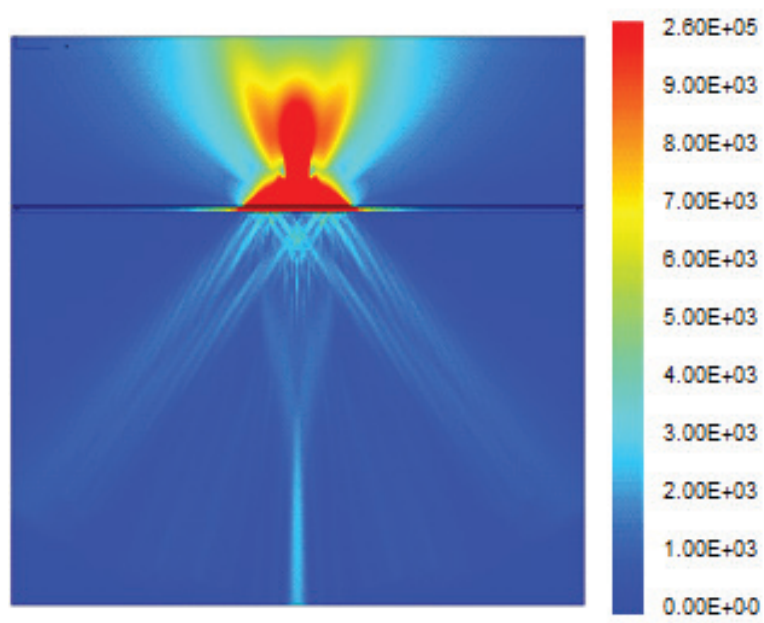

Figure 5: Maximum acoustic pressure of $n=64, p=30$ passedarraytransducerconfiguration.Colorscalevalues arein $\mathrm{Pa}$, while model domain dimensions are $10 \times 10 \mathrm{~mm}$.

This configuration also has a pronounced grating lobes formation because of a bit higher pitch value. To reduce this by keeping the pitch below $\lambda / 2$ and to keep the focusing capabilities at least above $15 \mathrm{~mm}$ it is necessary to further increase the electrodes number above, an already high, 64, compared to 16 electrodes at the start. Also with the 64 electrodes configuration, the transducer is still relatively compact in size, which brings benefits regarding possible applications.

The 64-electrodes configuration has better beam formation and better-focusing capabilities in comparison with 16 electrodes configuration. However, the sensitivity of both transducer configuration is poor. Due to a small pitch value (i.e., close electrode placement), which will provide a better beam formation and less scattering of the generated acoustic wave in water column, we have very pronounced crosstalk that affects transducers sensitivity in a way that reflections from barrier cannot be differentiated. This is visible on Figure 6 , where each colored line represents the received signal of the one of 64 elements. The difference between frontwall and backwall of the barrier should be much more pronounced.

An increase of pitch value will result in more pronounced scattering of the acoustic wave, but with re- duced crosstalk. To our estimate, pitch of $100 \mu \mathrm{m}$ will lead to better transducer performance regarding the quality of acquired signals.

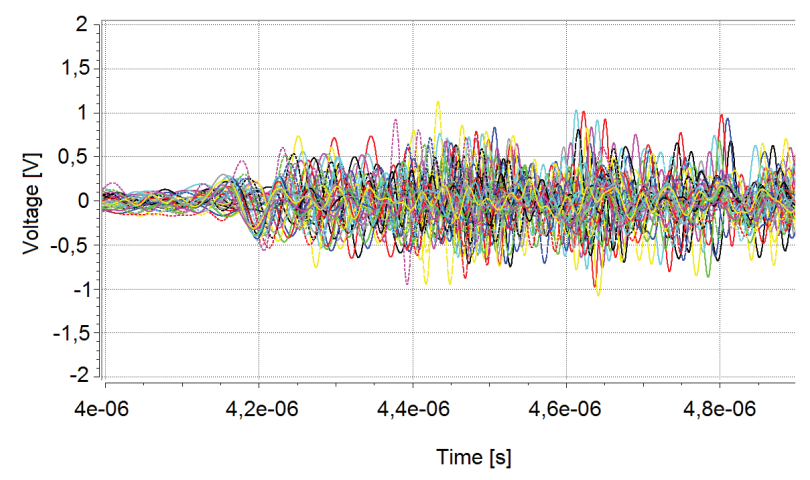

Figure 6: Crosstalk on received signal from a $0.450 \mathrm{~mm}$ thick barrier inside water column (for 64 electrodes configuration, pitch is $30 \mu \mathrm{m}$ ).

\section{Conclusions}

After conducted FEM simulations it is possible to conclude that the electrode pattern of considered transducers need at least 64 electrodes to obtain an optimal performance of a high-frequency miniature phased array ultrasound transducer on a PMN-PT thick piezoelectric film of central thickness mode vibration frequency of around $28.5 \mathrm{MHz}$. If one considers potential applications of this kind of transducers, in ophthalmological diagnostic tools for example, it is shown here that weak and technically unusable phased array transducer properties of a 16-electrodes configuration cannot probe the front part of an average eyeball, with a diameter around $24 \mathrm{~mm}$. The 64-electrode phased array configuration of a thick PMN-PT piezoelectric film of central thickness mode vibration frequency close to $30 \mathrm{MHz}$ could theoretically achieve a full depth ultrasound diagnostics coverage of an average human eye.

\section{Acknowledgments}

Ante Bilušić wish to thank to Dr Barbara Malič, Jožef Stefan Institute, Ljubljana, Slovenia for providing PMNPT samples. This research was partially supported under the project MEMSplit, Contract Number: RC.2.2.080052, a project funded by the European Union through the European Regional Development Fund - the Operational Programme Regional competitiveness 2007 - 2013 (RC.2.2.08). 


\section{References}

1. J.M. Cannata, J.A. Williams, Q.F. Zhou, T.A. Ritter, K.K. Shung, Development of a $35-\mathrm{MHz}$ piezocomposite ultrasound array for medical imaging, IEEE Transactions on Ultrasonics Ferroelectrics and Frequency Control 53 (2006) 224-236. https://doi.org/10.1109/TUFFC.2006.1588408

2. M. Lukacs, J. Yin, G. Pang, R.C. Garcia, E. Cherin, R. Williams, J. Mehi, F.S. Foster, Performance and characterization of new micromachined highfrequency linear arrays, IEEE Transactions on UItrasonics Ferroelectrics and Frequency Control 53 (2006) 1719-1729. https://doi.org/10.1109/TUFFC.2006.105

3. J.A. Brown, F.S. Foster, A. Needles, E. Cherin, G.R. Lockwood, Fabrication and performance of a linear array based on a 1-3 composite with geometric elevation focusing, IEEE Transactions on Ultrasonics Ferroelectrics and Frequency Control 54 (2007) 1888-1894. https://doi.org/10.1109/TUFFC.2007.473

4. C.G. Liu, Q.F. Zhou, F.T. Djuth, K.K. Shung, High-frequency $(>50 \mathrm{MHz})$ medical ultrasound linear arrays produced by micromachining bulk PZT materials, IEEE Transactions on Ultrasonics Ferroelectrics and Frequency Control 59 (2012) 315-318. https://doi.org/10.1109/TUFFC.2012.2193

5. Y. Ito, K. Kushida, K. Sugawara, H. Takeuchi, A 100 $\mathrm{MHz}$ ultrasonic transducer array using $\mathrm{ZnO}$ thin films, IEEE Transactions on Ultrasonics Ferroelectrics and Frequency Control 42 (1995) 316-324. https://doi.org/10.1109/58.365245

6. D.W. Wu, Q.F. Zhou, X.C Geng, C.G. Liu, F. Djuth, K.K. Shung, Very high frequency (beyond 100 $\mathrm{MHz}$ ) PZT kerfless linear arrays, IEEE Transactions on Ultrasonics Ferroelectrics and Frequency Control 56 (2009) 2304-2310. https://doi.org/10.1109/TUFFC.2009.1311

7. Q.F. Zhou, D.W.Wu, C.G. Liu, B.P. Zhu, F. Djuth, K.K. Shung, Micromachined high-frequency $(80 \mathrm{MHz})$ PZT thick film linear arrays, IEEE Transactions on Ultrasonics Ferroelectrics and Frequency Control 57 (2010) 2213. https://doi.org/10.1109/TUFFC.2010.1680

8. S.T. Lau, H. Li, K.S. Wong, Q.F. Zhou, D. Zhou, Y.C. Li, H.S. Luo, K.K. Shung, J.Y. Dai, Multiple matching scheme for broadband ${ }_{0.72} \mathrm{~Pb}\left(\mathrm{Mg}_{1 / 3} \mathrm{Nb}_{2 / 3}\right) \mathrm{O}_{3}-{ }_{0.28} \mathrm{PbTiO}_{3}$ single crystal phased-array transducer, Journal of Applied Physics 105 (2009) 094908. https://doi.org/10.1063/1.3065476

9. Q.F.Zhou, S.T. Lau, D.W.Wu, K.K. Shung, Piezoelectric films for high frequency ultrasonic transducers in biomedical applications, Progress in Materials Science 56 (2011) 139-174. https://doi.org/10.1016/j.pmatsci.2010.09.001
10. B.P. Zhu, D.W. Wu, Q.F. Zhou, J. Shi, K.K. Shung, Lead zirconate titanate thick film with enhanced electrical properties for high frequency transducer applications, Applied Physics Letters 93 (2008) 102905. https://doi.org/10.1063/1.2956408

11. Q.F. Zhou, C. Sharp, J.M. Cannata, K.K. Shung, G.H. Feng, E.S. Kim, Focused high frequency ZnO MEMS ultrasonic transducers for biomedical imaging, Applied Physics Letters 90 (2007) 113502. https://doi.org/10.1063/1.2712813

12. M. Kosec, J. Holc, D. Kuscer, S. Drnovsek, $\mathrm{Pb}\left(\mathrm{Mg}_{1 / 3} \mathrm{Nb}_{2 / 3}\right) \mathrm{O}_{3}-\mathrm{PbTiO}_{3}$ thick films from mechanochemically synthesized powder, Journal of the European Ceramic Society 27 (2007) 3775-3778. https://doi.org/10.1016/j.jeurceramsoc.2007.02.025

13. H. Ursic, M. Hrovat, J. Holc, M.S. Zarnik, S. Drnovsek, S. Macek, M. Kosec, A large-displacement ${ }_{65} \mathrm{~Pb}\left(\mathrm{Mg}_{1 / 3} \mathrm{Nb}_{2 / 3}\right) \mathrm{O}_{3}-{ }_{35} \mathrm{PbTiO}_{3} / \mathrm{Pt}$ bimorph actuator prepared by screen printing, Sensors and Actuators A: Physical 133 (2008) 699-704. https://doi.org/10.1016/j.snb.2008.04.004

14. J. Chen, H.Q. Fan, X.L. Chen, P.Y. Fang, C. Yang, S.J. Qiu, Fabrication of pyrochlore free PMN-PT thick films by electrophoretic deposition, Journal of Alloys and Compounds 471 (2009) L51-L53. https://doi.org/10.1016/j.jallcom.2008.06.088

15. D. Kuscer, M. Skalar, J. Holc, M. Kosec, Processing and properties of ${ }_{0.65} \mathrm{~Pb}\left(\mathrm{Mg}_{1 / 3} \mathrm{Nb}_{2 / 3}\right) \mathrm{O}_{3}-{ }_{0.35} \mathrm{PbTiO}_{3}$ thick films, Journal of the European Ceramic Society 29 (2009) 105-113.

https://doi.org/10.1016/j.jeurceramsoc.2008.06.010

16. W.S. Su, Y.F. Chen, W.Y. Shih, H.Y. Luo, W.H. Shih, Domain switching in lead magnesium niobatelead titanate polycrystalline sheets at single grain level, Applied Physics Letters 91 (2007) 112903. https://doi.org/10.1063/1.2778359

17. X. Li, W. Wei, Y.S. Chung, W.Y. Shih, W.H. Shih, Q.F. Zhou, K.K. Shung, 80-MHz intravascular ultrasound transducer using PMN-PT free-standing film, IEEE Transactions on Ultrasonics Ferroelectrics and Frequency Control 58 (2011) 2281-2288. https://doi.org/10.1109/TUFFC.2011.2085

18. B.P. Zhu, J.X. Han, J. Shi, K.K. Shung, Q. Wei, Y.H. Huang, M. Kosec, Q.F. Zhou, Lift-off PMN-PT thick film for high-frequency ultrasonic biomicroscopy, Journal of the European Ceramic Society 93 (2010) 2929-2931 https://doi.org/10.1111/j.1551-2916.2010.03873.x

19. B.P. Zhu, D.W.Wu, Y.Zhang, J. Ou-Yang, S. Chen, X.F. Yang, Sol-gel derived PMN-PT thick films for high frequency ultrasound linear array applications, Ceramics International 39 (2013) 8709-8714 https://doi.org/10.1016/j.ceramint.2013.04.054

20. M. Kosec, J. Holc, D. Kuscer, S. Drnovsek, $\mathrm{Pb}\left(\mathrm{Mg}_{1 / 3} \mathrm{Nb}_{2 / 3}\right) \mathrm{O}_{3}-\mathrm{PbTiO}_{3}$ thick films from mechanochemically synthesized powder, Journal of the 
European Ceramic Society 27 (2007) 3775-3778 https://doi.org/10.1016/j.jeurceramsoc.2007.02.025

21. D. Kuscer, E. Tchernychova Šturm, J. Kovač, and Marija Kosec, Characterization of the Amorphous Phase and the Nanosized Crystallites in High-Energy-Milled Lead-Magnesium-Niobate Powder, Journal of the American Ceramic Society 92 (2009) 1224-1229 https://doi.org/10.1111/j.1551-2916.2009.03091.x

22. FlexFA, PzFlex 2017 or OnScale platform; https://support.onscale.com/hc/en-us/ articles/360015260431-2-Materials-Geometry, https://support.onscale.com/hc/en-us/ articles/360007367631-4-Materials.

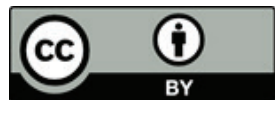

Copyright $\odot 2019$ by the Authors. This is an open access article distributed under the Creative Commons Attribution (CC BY) License (https://creativecommons.org/licenses/by/4.0/), which permits unrestricted use, distribution, and reproduction in any medium, provided the original work is properly cited.

Arrived: 31. 08. 2018

Accepted: 22. 01. 2019 